\title{
The use of an in vitro approach to assess marine invertebrate carboxylesterase responses to chemicals of environmental concern
}

Montserrat Solé ${ }^{1 *}$, Rosa Freitas ${ }^{2}$, Georgina Rivera-Ingraham ${ }^{3}$

${ }^{1}$ Institute of Marine Sciences (ICM-CSIC), Pg. Marítim de la Barceloneta 37-49, 08003 Barcelona, Spain.

${ }^{2}$ Department of Biology \& CESAM, Universidade de Aveiro, 3810-193 Aveiro, Portugal.

${ }^{3}$ Laboratorio de Fisiología y Genética Marina, Centro de Estudios Avanzados en Zonas Áridas, Universidad Católica del Norte, Larrondo 1281, Coquimbo, Chile.

\section{Highlights}

- An in vitro protocol for mammalian systems is appropriate to marine invertebrates

- Carboxylesterase substrates adequacy differs between human and invertebrates

- The flame retardant TBBPA interferes in vitro with carboxylesterases of all groups

\footnotetext{
Abstract

Carboxylesterases (CEs) are key enzymes which catalyse the hydrolysis reactions of multiple xenobiotics and endogenous ester moieties. Given their growing interest in the context of marine pollution and biomonitoring, this study focused on the in vitro sensitivity of marine invertebrate CEs to some pesticides, pharmaceuticals, personal
} 
care products and plastic additives to assess their potential interaction on this enzymatic system and its suitability as biomarkers. Three bivalves, one gastropod and two crustaceans were used and CEs were quantified following current protocols set for mammalian models. Four substrates were screened for CEs determination and to test their adequacy in the hepatic fraction measures of the selected invertebrates. Two commercial recombinant human isoforms (hCE1 and hCE2) were also included for methodological validation. Among the invertebrates, mussels were revealed as the most sensitive to xenobiotic exposures while gastropods were the least as well as with particular substrate-specific preferences. Among chemicals of environmental concern, the plastic additive tetrabromobisphenol A displayed the highest CE-inhibitory capacity in all species. Since plastic additives easily breakdown from the polymer and may accumulate and metabolise in marine biota, their interaction with the CE key metabolic/detoxification processes may have consequences in invertebrate's physiology, affect bioaccumulation and therefore trophic web transfer and, ultimately, human health as shellfish consumers.

Keywords: carboxylesterases, plastic additives, in vitro inhibition, bivalves, gastropods, crustacean.

\section{Introduction}

Marine ecosystems are the final sink for many land-based chemicals and this raises concerns on the toxicological consequences that man-made compounds may impose on aquatic wildlife and aquaculture species (Nilsen et al., 2019; Tornero and Hanke, 2016). In addition to the long list of classical chemical pollutants, there is a broad range of new drugs of environmental concern which have been more recently 
introduced into aquatic systems. Despite removal efforts of waste-water plants, technological limitations, accidental discharges and the high concentration and recalcitrant properties of some of these chemicals, make these substances reach marine systems (Sanchez-Avila et al., 2009). Among the latter, pharmaceuticals and personal care products (PPCPs) stand out, as they are increasingly used in a growing and aging population worldwide (Fent et al., 2006; Gaw et al., 2014). Consequently, there is increasing concern over the toxicological implications of PPCP exposures in aquatic species (Corcoran et al., 2010; Dussault et al., 2008; Fabbri and Franzellitti, 2016), including some particular drugs such as statins or lipid regulators (Santos et al., 2016). Plastics, and more particularly the additives included in their manufacturing process to improve some of their properties, are another group of chemicals of increasing environmental concern (Avio et al., 2017; Hermabessiere et al., 2017). Among them, brominated flame retardants (BFRs) had largely been used worldwide as plastic additives and reported to persist in aquatic environments (de Wit, 2002). Due to their widespread use and lipophilic nature, they are ubiquitously present in sewage sludge and even in marine sea-food in Europe (Aznar-Alemany et al., 2017; Gorga et al., 2013). Among them, tetrabromobisphenol A (TBBPA) and other bisphenol A derivatives can pose a threat to aquatic fauna because of its endocrine disrupting character and oxidative stress condition (Abdallah, 2016; Liu et al., 2018; PerezAlbadalejo et al 2020). Organophosphorus-based flame retardants such as Tris(1chloropropan-2-yl) phosphate (TCP) and triphenyl phosphate (TPP) have been introduced in the market to replace BFRs, as they have been reported to be less toxic (van der Veen and de Boer, 2012). However, there is recent evidence of their occurrence in high trophic level marine fauna, being able to cross the blood-brain barrier and accumulate in the brain (Sala et al., 2019). Another type of commonly-used 
plasticizers are phthalates, namely dimethyl phthalate (DMP), diethyl phthalate (DEP), di-isobutyl phthalate (DiBP), di-n-butyl phthalate (DnBP), benzylbutyl phthalate (BzBP) and di(2-ethylhexyl) phthalate (DEHP). These compounds have been detected in Mediterranean waters (Paluselli et al., 2018) and are known to be accumulated by zooplankton, posing a critical problem given their link position between primary producers and the upper levels of the marine trophic web (Schmidt et al., 2018). Recent evidences in marine shellfish species, including wild and farmed mussels confirm that plasticizers bioaccumulate in animal tissues: TCPP and phthalates may be found at about $20 \mathrm{ng} / \mathrm{g}$ d.w. and may reach up to $600 \mathrm{ng} / \mathrm{g}$ d.w. in the case of the more lipophilic DEHP (Castro-Jimenez and Rahola, 2020). Other plastic additives such as TCS, and more importantly its metabolite methyl-TCS, are also of concern due to their higher bioaccumulation potential in shellfish (Azzouz et al., 2019). Flame retardants, including TBBPA, as well as their metabolites have also been reported to bioccumulate in benthic and pelagic biota of the marine web (Choo et al., 2019).

Carboxylesterases (CEs) are members of the superfamily of $\alpha / \beta$ hydrolases involved in hydrolysis of endogenous compounds and detoxification of many chemicals of the ester, amide, thioester bonds and carbamates (Sogorb and Vilanova, 2002; Satoh and Hosokawa, 2006; Wheelock et al., 2008). In humans, two CE isoforms have been described to display a particular organ distribution and substrate preference: hCE1, mainly located in the liver and preferring substrates with a small alcohol or amine group and a large acyl moiety; and hCE2, located in intestine and extra-hepatic organs and showing preference for substrates with a large alcohol or amine and a small acyl moiety (Fukami and Yokoi, 2012; Hosokawa, 2008; Laizure et al., 2013). A large number of in vitro inhibition studies of this family of enzymes have been carried out and have been recognized as a useful tool for the evaluation of drug-drug interactions and drug 
development in pharmacology (Fukami et al., 2010; Imai et al., 2006; Takahashi et al., 2009; Xu et al., 2013). An adaptation of the former in vitro approach, currently used in mammalian systems, was here applied to reveal the potential interaction of drugs of environmental concern in hepatic CEs. In vitro experimentation has a number of limitations, including the fact that they use higher concentrations than those considered as environmentally realistic. Furthermore, they may not reflect the cell compartment interactions given that analyses are carried out under the lack of the metabolic and homeostasis processes which take place in vivo. Nevertheless, this approach was here adopted to conduct a first screening of a proxy of the potential interactions occurring invivo, and aiming to set the bases for further environmental studies. A selection was made of representative marine invertebrates of three phyla that constitute a large proportion of Mediterranean shellfish. Recent studies on marine bivalves have demonstrated the in vivo ability of CEs to metabolise drugs such as the retroviral Tamiflu ${ }^{\circledR}$ (Dallares et al., 2019) and to respond to the presence of pesticides in the environment (Dallares et al., 2018). The CEs in vitro sensitivity to pesticides, pharmaceutical drugs and plastic additives has also been reported in a large number of aquatic species (Nos et al., 2020; Ribalta et al., 2015; Sole and Sanchez-Hernandez, 2015; Sole and Sanchez-Hernandez, 2018). Gastropods CEs have also been revealed to be sensitive to pesticides but studies are largely based on freshwater species (Bianco et al., 2014; Laguerre et al., 2009; Otero and Kristoff, 2016). Marine gastropods such as Bolinus brandaris are considered as good sentinels of endocrine disrupting chemical pollution (e.g. organotin compounds, inducing imposex), a long-lasting concern in the Mediterranean (Anastasiou et al., 2016; Sole et al., 1998). CEs in marine crustaceans have also been targeted as biomarkers of chemical exposure (Anto et al., 2009; Sole et al., 2009; Varo et al., 2019). In the later, the juvenile hormone methyl farnesoate is 
metabolised by a particular type of CE. Since this hormone is involved in key physiological events, including moulting, metamorphosis and reproduction (Homola and Chang, 1997; Lee et al., 2011), any interactions of xenobiotics on CE hydrolytic activity are of physiological concern.

The aim of this study was to apply an in vitro approach, currently used in mammalian studies, to reveal interactions of toxic chemicals of environmental concern on hepatic CEs of selected marine shellfish invertebrates. For that, commercial recombinant human CEs were included in the in vitro exposures to validate the methodological approach. The selected species are representative elements of the marine food chain with a significant commercial interest NW Mediterranean region. Any drug interactions with CE activities which may affect shellfish physiological performance, drug metabolism capacity and bioaccumulation to ultimately infer on the consequences to wildlife and humans as shellfish consumers.

\section{Material and methods}

\subsection{Sample collection}

The present study considered three bivalves (the mussel Mytilus galloprovincialis, the cockle Cerastoderma edule and the razor shell Solen marginatus), the muricid gastropod Bolinus brandaris, the portunid crab Macropipus tuberculatus and the pandalid shrimp Plesionika martia. Representatives of all these species were collected in July 2019 from traditional fishing grounds of the NW Mediterranean (Spain) and immediately transported in cold conditions to the laboratory where they were dissected. For each of the selected species, the digestive glands of the 10 individuals were obtained for enzymatic measures, except for cockle for which 20 
specimens were used (pool of 2 digestive glands per sample) due to their smaller size. The selected organisms were, within each group, adults of similar size and in a same physiological stage of maturation (Table 1). Biometrics are reported as mean shell length (SL), length without siphonal canal (LWS) and carapace length (CL), for bivalves, gastropods and crustaceans, respectively. LWS was chosen for the gastropod instead of total length because it is more realistic due to the long and narrow siphonal canal frequently breaking due to manipulation. CL was measured between the posterior edge of the carapace and the right frontal notch. In all cases, animals were quickly transported to the laboratory under ice-block cooling conditions and immediately dissected before their use in the experimental procedures following CSIC protocols as described further below.

\subsection{Sample processing.}

Upon arrival from the fishing grounds, digestive glands/ hepatopancreas of the selected invertebrates were dissected by placing the animals under ice-cold conditions to minimize pain infliction. Dissected tissues were immediately frozen in liquid nitrogen and individually stored at $-80^{\circ} \mathrm{C}$ until analysis. Each sample was homogenized at a $1: 5(w: v)$ ratio with a phosphate buffer $(100 \mathrm{mM}, \mathrm{pH} 7.4)$ containing $150 \mathrm{mM} \mathrm{KCl}$, $1 \mathrm{mM}$ ethylenediaminetetraacetic acid (EDTA), and 1mM dithiothreitol (DTT). The post-mitochondrial S9 fractions, used to conduct the biochemical analysis, were obtained from each homogenate after $30 \mathrm{~min}$ centrifugation at $10,000 \mathrm{~g}$ and $4^{\circ} \mathrm{C}$. Two aliquots were made to perform baseline CE activity determinations and CE inhibition tests as described in section 2.3. 


\subsection{Biochemical determinations}

Baseline CE activities were measured in a first S9 fraction aliquot of the digestive glands/hepatopancreas of the all invertebrate species ( $n=10$ per species) using 4 different substrates: p-nitrophenyl acetate (pNPA), p-nitrophenyl butyrate (pNPB), $\alpha$ naphthyl acetate ( $\alpha \mathrm{NA})$ and $\alpha$-naphthyl butyrate $(\alpha \mathrm{NB})$. Substrate concentration was 1 $\mathrm{mM}$ and $0.25 \mathrm{mM}$ for nitrophenyl and naphthyl esters, respectively. Sample volume was in all cases $25 \mu \mathrm{L}$. However, the sample dilution was adjusted for each species and substrate to ensure linearity of the data within the 5-min timeframe of the spectrophotometric measures. The formation of $\mathrm{p}$-nitrophenol (pNPA and $\mathrm{pNPB}$ ) was recorded at $405 \mathrm{~nm}$ as described in Hosokawa and Satoh (2005), while naphthol ( $\alpha$ NA and $\alpha \mathrm{NB}$ ) was measured at $235 \mathrm{~nm}$ according to the Mastropaolo and Yourno (1981) method. Assay dilutions for hCE1 and hCE2 for each particular substrate have been recently described in Solé et al., (2020). Specific multi-well plates were used for assays using the visible (Nunc) or the ultraviolet (Grenier) wavelength ranges.

In vitro $\mathrm{CE}$ inhibition tests were conducted in the second $\mathrm{S} 9$ fraction subsample ( $n=6$ for each species). Each conveniently diluted sample was incubated at room temperature with either buffer (control), carrier (ethanol) and with one of the chemicals (pesticides, PPCPs and plastic additives) listed in Table 2. Since the selected chemicals display varied properties of solubility and lipophilia (log Kow) as indicated in Fig. 1, a compromise of a single concentration of $10^{-4} \mathrm{M}$ was adopted as currently followed in protocols based on mammalian models (Fukami et al,.2010; Shimizu et al., 2014). Nonetheless, a range of six concentrations of TBBPA (from $10^{-4}$ to $10^{-9} \mathrm{M}$ in well) was tested on pNPB-CE1 activity which revealed the inhibition was dose dependent following a polynomic second degree curve $\left(\mathrm{R}^{2}=0.9662\right)$. The fact that the carrier at its highest concentration $(0.1 \%)$ did not interfere in $\mathrm{CE}$ determinations was here confirmed 
as well as elsewhere (Solé and Sanchez-Hernandez, 2018). The use of up to $1.5 \%$ of organic solvent in the reaction mixture revealed no interferes with CE measures either (Shimizu et al., 2014). After an incubation period of $15 \mathrm{~min}$, residual CE activity was measured as described above using the four selected substrates and the resulting inhibitory action was defined as the residual $\mathrm{CE}$ activity with respect to the controls (100\%). For comparative and methodological validation purposes and to infer if a particular CE isoform may be preferentially inhibited, purified human recombinant enzymes from Sigma-Aldrich (hCE1,ref. E0162and hCE2,ref. E0412) were also included in the analyses using the 4 selected substrates. More detail on the CE inhibition test and purified protein CE dilutions is described elsewhere (Solé and SanchezHernandez, 2018; Solé et al., 2020).

Total protein content of the samples, to which enzymatic baseline CE activities were referred, was determined using the Bradford method (Bradford, 1976) adapted to microplate readings. The Bradford Bio-Rad Protein Assay reagent was used with bovine serum albumin (BSA; 0.05-1 mg/mL) as standard and absorbance was read at $595 \mathrm{~nm}$.

All CE baseline and in vitro inhibition measures were carried out in triplicates and at $25^{\circ} \mathrm{C}$ in a TECAN Infinite 200 microplate reader. Only linear reactions were considered and these were registered using the kinetic assays mode of Magellan V6.0 data analysis software.

\subsection{Statistics}

Baseline CE activities are presented as means \pm standard error of mean (SEM). The non-parametric Friedman's test was used to contrast the enzymatic measures 
carried out in each species with the four commercial substrates and, for each substrate among species. The Wilcoxon Signed Ranked test was then applied as post-hoc to reveal group differences. Intraspecific correlation between baseline CE activities ( $n=10$ for each invertebrate species) was made using Pearson's correlation coefficient after confirming that the normality and homoscedasticity assumptions were met (ShapiroWilk and Levene tests, respectively). For in vitro inhibition tests, the non-parametric Mann-Whitney test was used to contrast the data between each residual CE activity after incubations with the chemical of concern with respect to their controls $(n=6)$. For each invertebrate species, Pearson's correlation coefficients between residual CE activities using the 4 substrates were also calculated after the inhibition with the 12 selected chemicals as a proxy of the overlapping substrate specificity on the chemical action over CEs. Statistical analyses were carried out using SPSS System Software v19 and the significance level for data analyses was set at 0.05 .

\section{Results and discussion}

\subsection{Substrate preference and baseline CE activities in selected marine invertebrates}

In Table $1 \mathrm{CE}$ baseline activities in the hepatic organ are detailed for the six marine invertebrate species and substrates assayed. Regarding the bivalves, CE substrate preference (i.e. measures displaying higher hydrolysis rates) in the mussel and the cockle followed a similar, and statistically significant, trend: pNPA $<$ pNPB $<\alpha \mathrm{NA}<\alpha \mathrm{NB}$ (mussels: $\chi^{2}(2)=26.040, p<0.001$; cockles: $\chi^{2}(2)=$ $26.760, p<0.001)$. For razor shell (S. marginatus), however, hydrolysis rates with $\alpha$ NA were the highest $\left(\chi^{2}(2)=23.880, p<0.001\right)$, and was also the bivalve with the highest baseline activities recorded here and formerly (Dallares et al., 2018; Solé et al., 2018). 
The gastropod B. brandaris did not show a clear substrate preference, although $\alpha$ NA-

CE was significantly lower than the rest $\left(\chi^{2}(2)=10.200, p=0.017\right)$, and the hydrolysis rates were closer to those seen in mussels. In this case, terrestrial and freshwater snails are the closest phylogenetic source of comparison described in the literature, with works reporting a substrate preference for the naphthyl form. This is the case of Planorbarius corneus (for which 3 out of the 4 substrates tested were used in the present study) (Otero and Kristoff, 2016), or the garden snail Xeropicta derbentina (2 substrates common to those considered here) (Laguerre et al., 2009). In the studies with freshwater snails Chilina gibbosa (Bianco et al., 2013) and P. corneus (Rivadeneira et al., 2013) pNPB substrate was preferred over pNPA but the opposite trend was seen with Biomphalria straminea (Bianco et al., 2014). However, for the latter, a higher in vivo sensitivity to OP exposures when using pNPB in CE measures was observed (Bianco et al., 2014), which supports the choice of this substrate. In the present study, the crustaceans studied showed the highest baseline CE activities of all contrasted invertebrates (pNPA: $\chi^{2}(2)=39.714, p<0.001$; pNB: $\chi^{2}(2)=39.600, p<0.001 ; \alpha \mathrm{NA}$ : $\left.\chi^{2}(2)=45.029, p<0.001 ; \alpha \mathrm{NB}: \chi^{2}(2)=34.571, p<0.001\right)$. However, in terms of substrate preference, the highest hydrolysis rates were reached in M. tuberculatus with pNPB $\left(\chi^{2}(2)=27.000, p<0.001\right)$ while in $P$. martia with $\alpha$ NA $\left(\chi^{2}(2)=19.560, p<\right.$ 0.001). Moreover, activities in the latter species were from 1.6 up to 4.6 times higher depending on the substrate (Table 1). No other contrasts were possible with other marine crustaceans as formerly reported CE measures in this group were made using $S$ phenyl thioacetate, a substrate that also includes A-esterases (Wheelock et al., 2008).

\subsection{In vitro inhibition of human CEs to pesticides, pharmaceuticals and plastic} additives. 
The selection of BNPP and eserine was made given they are specific CE and esterase inhibitors, respectively. The choice of PPCPs and plastic additives (Table 2) was based on: i) their already reported capacity to interfere with specific mammalian CEs (references within Table 2) ii) their described CE modulation in marine species (Ribalta et al., 2015; Solé and Sanchez-Hernandez, 2015; 2018) and; iii) their environmental occurrence and bioaccumulation potential $\left(\log K_{\text {ow }}>3\right)$.

The inhibitory action of the selected chemicals was contrasted using 4 commercial substrates (pNPA, pNPB, $\alpha$ NA and $\alpha \mathrm{NB}$ ) with two recombinant $\mathrm{CE}$ enzymes (hCE1 and hCE2) to: i) identify the most sensitive substrate in the measures and, ii) to confirm the reported specificity over the 2 isoforms revealed in former studies (as indicated in Table 2) and thus validate our approach. Out of the four substrates assayed for in vitro CE modulation, only the results corresponding to the measures with pNPA and pNPB substrates are represented (Fig. 2A and B) given that these measures are the most frequently reported in the literature. They also displayed linearity, lower variability and, in general, a higher in vitro $\mathrm{CE}$ responsiveness to most chemicals. However, the totality of results on the 4 substrates assayed in human (but also in invertebrates) are provided as supplementary material (Table S1). Data are represented as percentage of residual CE activity in hCE1 and hCE2 independent samples after 15 min incubation with the corresponding chemicals.

The inhibitory action of BNPP (specific for CE) and eserine (broader esterase inhibitor) on recombinant human CEs was here confirmed. The use of pNPA and pNPB substrates showed that BNPP equally inhibited both recombinant hCE1 and hCE2 isoforms (92-98\%) while eserine acted mainly over hCE2 (88 and 95\% inhibition with pNPA and pNPB, respectively). The use of naphthyl derivate substrates (supplementary table S1) also rendered similar results in terms of high inhibition rates with BNPP for 
hCE1 and hCE2 using either $\alpha$ NA or $\alpha$ NB (96-98\% inhibition). With the naphthyl substrates, eserine also acted mainly on hCE2 (inhibition >90\%). The lipid regulators simvastatin and fenofibrate were selected to identify isoforms as they are described to act, in mammalian systems, preferentially on hCE1 and hCE2, respectively (Fukami et al., 2010; Shimizu et al., 2014). Under the present in vitro conditions, these former observations were also confirmed except when using $\alpha$ NB as substrate (Table S1). Loperamide was the choice to discriminate hCE2 (Quinney et al., 2005) and here confirmed when using pNPA $(\approx 85 \%$ inhibition $)$. The antimicrobial agent triclosan (TCS), used also as plastic additive, has been described as a potent CE inhibitor in mammals (Morisseau et al., 2009) and in the present study a significant inhibition of hCE1 $(91 \%)$ and hCE2 (87\%) was registered when using pNPA, to a lesser extend with pNPB (Fig 2A \& 1B) but also with $\alpha$ NA ( $>50 \%$ ) but not $\alpha$ NB (Table S1). Plastic additives are of increasing environmental concern due to their widespread use, environmental presence and potential interaction on human CEs. Among them, the flame retardant TBBPA was revealed as a potent inhibitor of hCE1 $(86 \%)$ mainly when using pNPA as also seen in several marine organisms (Nos et al., 2020). An inhibitory action in human liver microsomes was also revealed by Zhu et al (2017) due to TBBPA and other BPA-analogues using fluorescein diacetate as specific hCE2 substrate. The organophosphorus flame retardant TCPP, acted mainly over hCE2 (42\% inhibition) and pNPA was seen as the most adequate for recombinant human CE measures. TPP, a related organophosphorus flame retardant, was also responsible for hCE1 and hCE2 inhibition in a nuclear receptor-based bioassay at the $\approx 50 \mathrm{nM}$ range (Morisseau et al., 2009). Phthalates such as DMP inhibited hCE1 by $50 \%$ while diBP inhibited more specifically hCE2 (54\%) being, once more, pNPA the most adequate substrate (Fig 2A \& 1B). By contrast, the phthalates DnBP and DEHP did not acted over any human 
recombinant $\mathrm{CE}$ form. Contrarily, their inclusion yielded a slight increase in activity $(\approx 10 \%)$ with respect to controls. This could be explained by their binding to the allosteric site of the enzyme that would cause a conformation change as reported for some BPA analogues (Zhu, 2017). Moreover, di-phthalates are metabolised to their mono-derivatives by the hydrolytic action of CEs in mammalian systems (Ozaki et al., 2017), and some of these metabolites possess higher endocrine disruption potential (Chauvigne et al., 2011) and cause severer oxidative stress conditions (Pérez-Albadalejo et al., 2020) than the parent compounds.

The correlation coefficient between the percentages of residual CE activities after in vitro independent incubations with the 12 chemicals was assayed with the 4 selected substrates as a proxy of the similitudes on the drug action over 4 potential isoforms (Table S2). When considering the same recombinant isoform independently (hCE1 or hCE2), a positive and similar response was reached using the 4 substrates ( $>0.9)$, suggesting a high degree of overlapping substrate specificity. But this correlation was non-significant or markedly lower when using $\alpha \mathrm{NB}$ as substrate $(r>0.7)$. When comparing the responses to these 12 chemicals using the 4 substrates but contrasting to the two isoforms (hCE1 and hCE2), as expected, the correlations were low $(\mathrm{r}<0.5)$ and not significant, except when considering $\alpha \mathrm{NB}(\mathrm{r}>0.6 ; \mathrm{p}<0.05)$. Altogether, these results confirm an action of the drugs over each isoform (hCE1 and hCE2) and the adequacy of pNPA in human recombinant CE measures. This, furthermore, encourages the application of this methodological approach to screen the action of the targeted compounds in hepatic CEs of marine invertebrates. 


\subsection{In vitro inhibition of invertebrate CEs to pesticides, pharmaceuticals and plastic additives.}

In contrast to recombinant human CE responses, there was an apparent lack of in vitro sensitivity of invertebrate CEs to the pesticides, PPCPs and plastic additives. This could be explained by the presence of several proteins in the $S 9$ fraction as justified by Shimizu et al. (2014) when contrasting liver microsomal fractions and purified proteins. Nevertheless, the inhibitory action of the model CE inhibitor BNPP $(100 \mu \mathrm{M})$ allowed to confirm its high variable- and substrate- dependant CE contribution (i.e. higher inhibition) in the S9 fraction of marine invertebrates (Fig. 3). Of the 4 assayed substrates, pNPB proved to be, on average, the most adequate for invertebrates, while pNPA resembled the most adequate for human isoforms as indicated before. CE contribution, revealed after BNPP incubation and measured as percentage of inhibition in respect to controls (100\% maximal activity), followed the order: M. galloprovincialis $(79 \%)>$ E. siliqua $(74 \%)>$ M. tuberculatus $(67 \%)>P$. martia $(63 \%)>$ C. edule $(56 \%)>$ B. brandaris $(25 \%)$. In bivalves, a clear preference for butyrate-derived forms was confirmed with a greater inhibition of baseline CE activity achieved with these substrates as formerly described (Nos et al., 2020; Solé et al., 2018; Solé and SanchezHernandez, 2018). For the other invertebrate groups, substrate preference was not as clear (supplementary material S1); nonetheless, a compromise was reached to adopt pNPB in invertebrate measures as formerly suggested (Nos et al., 2020).

As done with human CE recombinant isoforms, CE-related measures in invertebrates were contrasted in vitro to the selected chemicals of concern. In particular, eserine, TCS, TBBPA and TCPP were selected for species contrasts (Fig. 4) given they have been formerly reported to interact with human CEs and are likely going to affect marine invertebrate CEs as well due to their conservative nature. Eserine caused the 
largest CE inhibition in the crustacean species, with P. martia and M. tuberculatus showing $67 \%$ and $57 \%$ inhibition over controls (100\%), respectively. This is in line with the high in vivo and in vitro sensitivity of crustaceans to pesticides (Antó et al., 2009; Nunes, 2011). Among the bivalves, the cockle (C. edule) was more sensitive to in vitro $\mathrm{CE}$ inhibition than the mussel (M. galloprovincialis) with $41 \%$ and $23 \%$ inhibition of the control activities, respectively. TCS exposure $(100 \mu \mathrm{M})$ in vitro affected mussel CEs causing a $72 \%$ inhibition of the activity, corroborating previous results (Solé and Sanchez-Hernandez, 2018), while its effects on crustaceans was more moderate albeit significant $(\approx 20 \%)$. TCS is able to accumulate in bivalves and cause in vivo metabolic disturbances (Costa et al., 2020; Kookana et al., 2013; Matozzo et al., 2012; Pirone et al., 2019; Serra-Compte et al., 2018) but no inclusion of CE measures had been considered in these former studies. TCS toxicity was assessed in the marine decapod crustacean Palaemon varians using an avoidance test (Araujo et al., 2019) and in the marine gastropod Haliotis tuberculate through in vitro toxicity tests using gill cell cultures and hemocytes (Gaume et al., 2013). TBBPA was revealed as the chemical to exert the highest inhibitory potential in mussels $(67 \%)$ and also in the crustaceans $(M$. tuberculatus by $48 \%$ and $M$. martia by $28 \%$ of their respective basal activities). The TBBPA high in vitro inhibitory potential was formerly described in mussels and other marine species including zooplankton crustacean (Nos et al., 2020). An inhibition of CE basal activities was also registered in the bivalve $S$. marginatus and the gastropod $B$. brandaris but due to the larger variability on the in vitro responses, statistical significance was not reached. The flame retardant TCPP did not induce the in vitro inhibition of CEs in any of the selected invertebrates although it selectively inhibited the human hCE2 form. The isoform composition in invertebrates has not yet been described although it could be inferred based on the results obtained from inhibitions by 
simvastatin (acting on hCE1) and fenofibrate and/or loperamide incubations (acting on hCE2). However, no clear specific CE isoform composition could be deduced from any of the inhibitors in the $S 9$ fraction of the selected invertebrates with any of the 4 assay substrates (Supplementary material Table S1). Despite the lower in vitro sensitivity using protein homogenate mixtures, the fact that many OPFRs are present and accumulate in marine organisms, including in the brain of marine mammals (Sala et al., 2019), highlights the necessity of further studying this subject, at least, in the most sensitive marine species. In contrast to mammalians, invertebrate CEs were not clearly modulated by phthalates: activities fluctuated $\pm 10 \%$ of the controls and only a remarkable $33 \%$ inhibition of $\alpha$ NB-CE activity was revealed in the crustacean $M$. tuberculatus (supplementary data Table S1). In fact, it was in this portunid crustacean that this $\alpha \mathrm{NB}-\mathrm{CE}$ measure was the most sensitive one. Growing concern for plastics in the marine environment has revealed that microplastics (and consequently their additive components) are found in marine organisms such as molluscs (Abidli et al., 2019; Ben Ameur et al., 2020; Hermabessiere et al., 2019; Renzi et al., 2018) and crustaceans (Bordbar et al., 2018; Carreras-Colom et al., 2020; Carreras-Colom et al., 2018). Recently a study with the estuarine crustacean Artemia franciscana exposed to microplastics revealed that $\mathrm{CE}$ activity (using pNPA for the measurements) was inhibited (Varo et al., 2019). However, the authors were unable to relate if the toxicity was due to the polymer itself or to its additives. Since phthalates are metabolised by CEs (Ozaki et al, 2017) and the fact that some of their metabolites can be more toxic than the parental compound (e.g DEHP to MEHP), the study of the in vivo toxicity assessment in marine invertebrates requires investigation. Nevertheless, a relatively easy and fast first in vitro screening using hepatic homogenates of marine species based on mammalian protocols could be an interesting and more immediate approach. Despite 
the general literature consensus on the use of pNPB in invertebrate species comparisons, the naphthyl-derived substrate $(\alpha \mathrm{NB})$ turned out to be more sensitive and revealed species particularities after in vitro inhibitions for some particular chemicals. That is, between the two crustaceans, $M$. tuberculatus was overall more responsive to the inhibitory action of the chemicals and there was an apparent lack of in vitro responses in the gastropod for most chemicals except TBBPA (Table S1). Moreover, CE measures with the other naphthyl substrate ( $\alpha \mathrm{NA}$ ) revealed higher sensitivity in terms of inhibitory action due to simvastatin, fenofibrate, loperamide and triclosan incubations $(100 \mu \mathrm{M})$ in the gastropod and the two selected crustaceans (supplementary material Table S1). This observation supports the need to test more than one substrate in CE measures in order to identify the most adequate one for each species.

The correlation coefficient registered between the inhibitory action of the 12 selected chemicals using the 4 substrates was also tested in invertebrates and it was seen as high and species dependent (Table S2). All correlations were significant $(\mathrm{p}<0.01)$ in M. galloprovincials $(\mathrm{r}=0.736-0.948)$, C. edule $(\mathrm{r}=0.897-0.971)$, B. brandaris $(\mathrm{r}=$ $0.662-0.885)$ and $P$. martia $(\mathrm{r}=0.867-0.991)$. These correlations were also significant in the case of the razor shell ( $S$. marginatus) $(\mathrm{r}=0.775-0.946)$ and in $M$. tuberculatus ( $r=0.628-0.912$ ) but lower when including $\alpha \mathrm{NB}$ or $\alpha \mathrm{NA}$, respectively, in the measures. This suggests the occurrence of several isoforms in the selected species, despite a high degree of overlapping substrate specificity due to the promiscuous nature of $\mathrm{CE}$ enzymes.

\section{Conclusions.}


The in vitro approach used in this study, adopted from mammalian studies, confirmed the selectivity of certain drugs to modulate particular CE isoforms in humans, and confirmed its methodological suitability to be applied to other biological groups. Despite a lower responsiveness when using S9 fractions of hepatic organs of marine invertebrates we were still able to identify CE-related measures and the most sensitive substrate for each species. The substrate pNPA was confirmed as the most adequate for human recombinant $\mathrm{CE}$ isoforms whereas $\mathrm{pNPB}$ would be the best choice for the tested invertebrate species despite certain species-specific preferences. As a first screening test, this relatively fast throughput method using a battery of CE substrates highlights how these chemicals of high environmental concern may pose a threat to aquatic species. However, lower environmentally realistic concentrations should be tested for each particular chemical and species of interest. Since many of them accumulate in marine organisms, including some of commercial interest, concern for human health should be raised due to the likely exposure to these chemicals through the food chain.

Credit_authorship

MS participated in Conceptualization, Investigation, Funding acquisition and writing the original draft. GR and RF participated in formal analysis and writing, review and editing the final manuscript.

Declaration of interests

The authors declare that they have no known competing financial interests or personal relationships that could have appeared to influence the work reported in this paper.

\section{Acknowledgements}


This work was financed by Spanish Ministry of Economy, Industry and Competitivity (ref CGL2016-76332-R MINECO/FEDER, UE). SAP-ICATMAR is acknowledged for providing biological samples. Two of us (M.S and R.F) are member of the CYTED network RIESCOS ref. 419RT0578. 


\section{References}

Abdallah, M.A.-E., 2016. Environmental occurrence, analysis and human exposure to the flame retardant tetrabromobisphenol-A (TBBP-A)-A review. Environ. Int. 94, 235-250.

Abello, P., Pertierra, J.P., Reid, D.G., 1990. Sexual size dimorphism, relative growth and handedness in Liocarcinus depurator and Macropipus tuberculatus (Brachyura: Portunidae). Sci. Mar. 54, 195-202.

Abidli, S., Lahbib, Y., El Menif, N.T., 2019. Microplastics in commercial molluscs from the lagoon of Bizerte (Northern Tunisia). Mar. Pollut. Bull. 142, 243-252.

Anastasiou, T.I., Chatzinikolaou, E., Mandalakis, M., Arvanitidis, C., 2016. Imposex and organotin compounds in ports of the Mediterranean and the Atlantic: Is the story over? Sci. Total Environ. 569, 1315-1329.

Anto, M., Arnau, S., Buti, E., Cortijo, V., Gutierrez, E., Sole, M., 2009.

Characterisation of integrated stress biomarkers in two deep-sea crustaceans, Aristeus antennatus and Nephrops norvegicus, from the NW fishing grounds of the Mediterranean sea. Ecotox. Environ. Safe. 72, 1455-1462.

Araujo, C.V.M., Gomez, L., Silva, D.C.V.R., Pintado-Herrera, M.G., Lara-Martin, P.A., Hampel, M., Blasco, J., 2019. Risk of triclosan based on avoidance by the shrimp Palaemon varians in a heterogeneous contamination scenario: How sensitive is this approach? Chemosphere 235, 126-135.

Avio, C.G., Gorbi, S., Regoli, F., 2017. Plastics and microplastics in the oceans: From emerging pollutants to emerged threat. Mar. Environ. Res. 128, 2-11.

Aznar-Alemany, O., Trabalon, L., Jacobs, S., Barbosa, V.L., Fernandez Tejedor, M., Granby, K., Kwadijk, C., Cunha, S.C., Ferrari, F., Vandermeersch, G., Sioen, I., Verbeke, W., Vilavert, L., Domingo, J.L., Eljarrat, E., Barcelo, D., 2017. 
Occurrence of halogenated flame retardants in commercial seafood species available in European markets. Food Chem. Toxicol. 104, 35-47.

Azzouz, A., Palacios Colon, L., Souhail, B., Ballesteros, E., 2019. A multi-residue method for GC-MS determination of selected endocrine disrupting chemicals in fish and seafood from European and North African markets. Environ. Res. 178, 108727.

Ben Ameur, W., Annabi, A., El Megdiche, Y., Mhadhbi, T., Ben Hassine, S., Barhoumi, B., Touil, S., Driss, M.R., Barcelo, D., Eljarrat, E., 2020. Legacy and Emerging Brominated Flame Retardants in Bizerte Lagoon Murex (Hexaplex Trunculus): Levels and Human Health Risk Assessment. Arch. Environ. Contam. Toxicol. 78, 337-349.

Bianco, K., Otero, S., Oliver, A.B., Nahabedian, D., Kristoff, G., 2014. Resistance in cholinesterase activity after an acute and subchronic exposure to azinphos-methyl in the freshwater gastropod Biomphalaria straminea. Ecotox. Environ. Safe. 109, $85-92$.

Bianco, K., Yusseppone, M.S., Otero, S., Luquet, C., Rios de Molina, M.C., Kristoff, G., 2013. Cholinesterases and neurotoxicity as highly sensitive biomarkers for an organophosphate insecticide in a freshwater gastropod (Chilina gibbosa) with low sensitivity carboxylesterases. Aquat. Toxicol. 144, 26-35.

Bordbar, L., Kapiris, K., Kalogirou, S., Anastasopoulou, A., 2018. First evidence of ingested plastics by a high commercial shrimp species (Plesionika narval) in the eastern Mediterranean. Mar. Pollut. Bull. 136, 472-476.

Bradford, M.M., 1976. Rapid and sensitive method for quantitation of microgram quantities of protein utilizing principle of protein-dye binding. Anal. Biochem. 72, 248-254. 
Carbonell, A., Abello, P., 1998. Distribution characteristics of pandalid shrimps (Decapoda : Caridea : Pandalidae) along the western Mediterranean Sea. Journal of Natural History 32, 1463-1474.

Carreras-Colom, E., Constenla, M., Soler-Membrives, A., Cartes, J.E., Baeza, M., Carrasson, M., 2020. A closer look at anthropogenic fiber ingestion in Aristeus antennatus in the NW Mediterranean Sea: Differences among years and locations and impact on health condition. Environ. Pollut. 263.

Carreras-Colom, E., Constenla, M., Soler-Membrives, A., Cartes, J.E., Baeza, M., Padros, F., Carrasson, M., 2018. Spatial occurrence and effects of microplastic ingestion on the deep-water shrimp Aristeus antennatus. Mar. Pollut. Bull. 133, 44-52.

Castro-Jimenez, J., Ratola, N., 2020. An innovative approach for the simultaneous quantitative screening of organic plastic additives in complex matrices in marine coastal areas. Environ. Sci. Pollut. Res, 27, 11450-11457.

Choo, G., Lee, I.-S., Oh, J.-E., 2019. Species and habitat-dependent accumulation and biomagnification of brominated flame retardants and PBDE metabolites. J. Hazard. Mater. 371, 175-182.

Corcoran, J., Winter, M.J., Tyler, C.R., 2010. Pharmaceuticals in the aquatic environment: A critical review of the evidence for health effects in fish. Critical Reviews in Toxicology 40, 287-304.

Costa, S., Coppola, F., Pretti, C., Intorre, L., Meucci, V., Soares, A.M.V.M., Sole, M., Freitas, R., 2020. Biochemical and physiological responses of two clam species to Triclosan combined with climate change scenario. The Science of the total environment 724, 138143-138143. 
Chauvigne, F., Plummer, S., Lesne, L., Cravedi, J.-P., Dejucq-Rainsford, N., Fostier, A., Jegou, B., 2011. Mono-(2-ethylhexyl) Phthalate Directly Alters the Expression of Leydig Cell Genes and CYP17 Lyase Activity in Cultured Rat Fetal Testis. Plos One 6.

Dallares, S., Carrasco, N., Alvarez-Munoz, D., Rambla-Alegre, M., Sole, M., 2018. Multibiomarker biomonitoring approach using three bivalve species in the Ebro Delta (Catalonia, Spain). Environ. Sci. Pollut. Res, 25, 36745-36758.

Dallares, S., Montemurro, N., Perez, S., Rodriguez-Sanchez, N., Sole, M., 2019.

Preliminary results on the uptake and biochemical response to water-exposure of Tamiflu (R) (oseltamivir phosphate) in two marine bivalves. Journal of Toxicology and Environmental Health-Part a-Current Issues 82, 75-85.

de Wit, C.A., 2002. An overview of brominated flame retardants in the environment. Chemosphere 46, 583-624.

Dussault, E.B., Balakrishnan, V.K., Sverko, E., Solomon, K.R., Sibley, P.K., 2008. Toxicity of human pharmaceuticals and personal care products to benthic invertebrates. Environ. Toxicol. Chem. 27, 425-432.

Fabbri, E., Franzellitti, S., 2016. Human pharmaceuticals in the marine environment: focus on exposure and biological effects in animal species. Environ. Toxicol. Chem. 35, 799-812.

Fent, K., Weston, A.A., Caminada, D., 2006. Ecotoxicology of human pharmaceuticals. Aquat. Toxicol. 76, 122-159.

Fukami, T., Takahashi, S., Nakagawa, N., Maruichi, T., Nakajima, M., Yokoi, T., 2010. In Vitro Evaluation of Inhibitory Effects of Antidiabetic and Antihyperlipidemic Drugs on Human Carboxylesterase Activities. Drug Metabolism and Disposition $38,2173-2178$. 
Fukami, T., Yokoi, T., 2012. The Emerging Role of Human Esterases. Drug Metabolism and Pharmacokinetics 27, 466-477.

Gaume, B., Bourgougnon, N., Auzoux-Bordenave, S., Roig, B., Le Bot, B., Bedoux, G., 2013. Cytotoxic effects of in vitro exposure to triclosan on the marine gastropod Haliotis tuberculata. Cytotechnology 65, 687-687.

Gaw, S., Thomas, K.V., Hutchinson, T.H., 2014. Sources, impacts and trends of pharmaceuticals in the marine and coastal environment. Philosophical transactions of the Royal Society of London. Series B, Biological sciences 369.

Gorga, M., Martinez, E., Ginebreda, A., Eljarrat, E., Barcelo, D., 2013. Determination of PBDEs, HBB, PBEB, DBDPE, HBCD, TBBPA and related compounds in sewage sludge from Catalonia (Spain). Sci. Total Environ. 444, 51-59.

Hatfield, M.J., Potter, P.M., 2011. Carboxylesterase inhibitors. Expert Opinion on Therapeutic Patents 21, 1159-1171.

Hermabessiere, L., Dehaut, A., Paul-Pont, I., Lacroix, C., Jezequel, R., Soudant, P., Duflos, G., 2017. Occurrence and effects of plastic additives on marine environments and organisms: A review. Chemosphere 182, 781-793.

Hermabessiere, L., Paul-Pont, I., Cassone, A.-L., Himber, C., Receveur, J., Jezequel, R., El Rakwe, M., Rinnert, E., Riviere, G., Lambert, C., Huvet, A., Dehaut, A., Duflos, G., Soudant, P., 2019. Microplastic contamination and pollutant levels in mussels and cockles collected along the channel coasts. Environ. Pollut. 250, 807819.

Homola, E., Chang, E.S., 1997. Distribution and regulation of esterases that hydrolyze methyl farnesoate in Homarus americanus and other crustaceans. Gen. Comp. Endocr. 106, 62-72. 
Hosokawa, M., 2008. Structure and catalytic properties of carboxylesterase isozymes involved in metabolic activation of prodrugs. Molecules 13, 412-431.

Hosokawa, M., Satoh, T., 2005. Measurement of carboxylesterase (CES) activities. In: Costa, L.G., Hodgson, E., Lawrence, D.A., Ozolins T.R., Reed D.J., Greenlee, W.F. (Eds.), Current Protocols in Toxicology, John Wiley \& Sons, chapter 4, unit 4.7 .

Imai, T., Taketani, M., Shii, M., Hosokawa, M., Chiba, K., 2006. Substrate specificity of carboxylesterase isozymes and their contribution to hydrolase activity in human liver and small intestine. Drug Metabolism and Disposition 34, 1734-1741.

Kookana, R.S., Shareef, A., Fernandes, M.B., Hoare, S., Gaylard, S., Kumar, A., 2013. Bioconcentration of triclosan and methyl-triclosan in marine mussels (Mytilus galloprovincialis) under laboratory conditions and in metropolitan waters of Gulf St Vincent, South Australia. Mar. Pollut. Bull. 74, 66-72.

Laguerre, C., Sanchez-Hernandez, J.C., Kohler, H.R., Triebskorn, R., Capowiez, Y., Rault, M., Mazzia, C., 2009. B-type esterases in the snail Xeropicta derbentina: An enzymological analysis to evaluate their use as biomarkers of pesticide exposure. Environ. Pollut. 157, 199-207.

Laizure, S.C., Herring, V., Hu, Z., Witbrodt, K., Parker, R.B., 2013. The Role of Human Carboxylesterases in Drug Metabolism: Have We Overlooked Their Importance? Pharmacotherapy 33, 210-222.

Lee, S.-O., Jeon, J.-M., Oh, C.-W., Kim, Y.M., Kang, C.-K., Lee, D.-S., Mykles, D.L., Kim, H.-W., 2011. Two juvenile hormone esterase-like carboxylesterase cDNAs from a Pandalus shrimp (Pandalopsis japonica): Cloning, tissue expression, and effects of eyestalk ablation. Comp. Biochem. Physiol. B. 159, 148-156. 
Liu, A., Zhao, Z., Qu, G., Shen, Z., Shi, J., Jiang, G., 2018. Transformation/degradation of tetrabromobisphenol A and its derivatives: A review of the metabolism and metabolites. Environ. Pollut. 243, 1141-1153.

Martin, P., Sanchez, P., Ramon, M., 1995. Population-structure and exploitation of bolinus-brandaris (mollusca, gastropoda) off the catalan coast (northwestern mediterranean). Fish. Res. 23, 319-331.

Mastropaolo, W., Yourno, J., 1981. An ultraviolet spectrophotometric assay for $\alpha$ naphthyl acetate and $\alpha$-naphthyl butyrate esterases. Anal. Biochem. 115, 188-193.

Matozzo, V., Formenti, A., Donadello, G., Marin, M.G., 2012. A multi-biomarker approach to assess effects of Triclosan in the clam Ruditapes philippinarum. Mar. Environ. Res. 74, 40-46.

Morisseau, C., Merzlikin, O., Lin, A., He, G., Feng, W., Padilla, I., Denison, M.S., Pessah, I.N., Hammock, B.D., 2009. Toxicology in the Fast Lane: Application of High-Throughput Bioassays to Detect Modulation of Key Enzymes and Receptors. Environ. Health Perspect. 117, 1867-1872.

Nilsen, E., Smalling, K.L., Ahrens, L., Gros, M., Miglioranza, K.S.B., Pico, Y., Schoenfuss, H.L., 2019. Critical review: Grand challenges in assessing the adverse effects of contaminants of emerging concern on aquatic food webs. Environ. Toxicol. Chem. 38, 46-60.

Nos, D., Navarro, J., Saiz, E., Sanchez-Hernandez, J.C., Sole, M., 2020.

Tetrabromobisphenol A inhibits carboxylesterase activity of marine organisms from different trophic levels. Chemosphere 238.

Nunes, B., 2011. The Use of Cholinesterases in Ecotoxicology, in: Whitacre, D.M. (Ed.), Reviews of Environmental Contamination and Toxicology, Vol 212, pp. 29-59. 
Otero, S., Kristoff, G., 2016. In vitro and in vivo studies of cholinesterases and carboxylesterases in Planorbarius corneus exposed to a phosphorodithioate insecticide: Finding the most sensitive combination of enzymes, substrates, tissues and recovery capacity. Aquat. Toxicol. 180, 186-195.

Ozaki, H., Sugihara, K., Watanabe, Y., Moriguchi, K., Uramaru, N., Sone, T., Ohta, S., Kitamura, S., 2017. Comparative study of hydrolytic metabolism of dimethyl phthalate, dibutyl phthalate and di(2-ethylhexyl) phthalate by microsomes of various rat tissues. Food Chem. Toxicol. 100, 217-224.

Paluselli, A., Fauvelle, V., Schmidt, N., Galgani, F., Net, S., Sempere, R., 2018. Distribution of phthalates in Marseille Bay (NW Mediterranean Sea). Sci. Total Environ. 621, 578-587.

Pérez-Albadalejo, E., Solé, M., Porte, C., 2020. Plastics and plastic additives as inducers of oxidativestress. Current Opinion Toxicol. 2020, 20-21:69-76.

Pirone, G., Coppola, F., Pretti, C., Soares, A.M.V.M., Sole, M., Freitas, R., 2019. The effect of temperature on Triclosan and Lead exposed mussels. Comp. Biochem. Physiol. B. 232, 42-50.

Quinney, S.K., Sanghani, S.P., Davis, W.I., Hurley, T.D., Sun, Z., Murry, D.J., Bosron, W.F., 2005. Hydrolysis of capecitabine to 5 '-deoxy-5-fluorocytidine by human carboxylesterases and inhibition by loperamide. Journal of Pharmacology and Experimental Therapeutics 313, 1011-1016.

Renzi, M., Guerranti, C., Blaslovic, A., 2018. Microplastic contents from maricultured and natural mussels. Mar. Pollut. Bull. 131, 248-251.

Ribalta, C., Sanchez-Hernandez, J.C., Sole, M., 2015. Hepatic biotransformation and antioxidant enzyme activities in Mediterranean fish from different habitat depths. Sci. Total Environ. 532, 176-183. 
Rivadeneira, P.R., Agrelo, M., Otero, S., Kristoff, G., 2013. Different effects of subchronic exposure to low concentrations of the organophosphate insecticide chlorpyrifos in a freshwater gastropod. Ecotox. Environ. Safe. 90, 82-88.

Sala, B., Gimenez, J., de Stephanis, R., Barcelo, D., Eljarrat, E., 2019. First determination of high levels of organophosphorus flame retardants and plasticizers in dolphins from Southern European waters. Environ. Res. 172, 289295.

Sanchez-Avila, J., Bonet, J., Velasco, G., Lacorte, S., 2009. Determination and occurrence of phthalates, alkylphenols, bisphenol A, PBDEs, PCBs and PAHs in an industrial sewage grid discharging to a Municipal Wastewater Treatment Plant. Sci. Total Environ. 407, 4157-4167.

Santos, M.M., Ruivo, R., Lopes-Marques, M., Torres, T., de los Santos, C.B., Castro, L.F.C., Neuparth, T., 2016. Statins: An undesirable class of aquatic contaminants? Aquat. Toxicol. 174, 1-9.

Satoh, T., Hosokawa, M., 2006. Structure, function and regulation of carboxylesterases. Chem. Biol. Interact. 162, 195-211.

Schmidt, N., Castro-Jimenez, J., Fauvelle, V., Sempere, R., 2018. Zooplankton and Plastic Additives-Insights into the Chemical Pollution of the Low-Trophic Level of the Mediterranean Marine Food Web, in: Cocca, M., DiPace, E., Errico, M.E., Gentile, G., Montarsolo, A., Mossotti, R. (Eds.), Proceedings of the International Conference on Microplastic Pollution in the Mediterranean Sea.

Serra-Compte, A., Maulvault, A.L., Camacho, C., Alvarez-Munoz, D., Barcelo, D., Rodriguez-Mozaz, S., Marques, A., 2018. Effects of water warming and acidification on bioconcentration, metabolization and depuration of 
pharmaceuticals and endocrine disrupting compounds in marine mussels (\&ITMytilus galloprovincialis\&IT). Environ. Pollut. 236, 824-834.

Shimizu, M., Fukami, T., Nakajima, M., Yokoi, T., 2014. Screening of Specific Inhibitors for Human Carboxylesterases or Arylacetamide Deacetylase. Drug Metabolism and Disposition 42, 1103-1109.

Sogorb, M.A., Vilanova, E., 2002. Enzymes involved in the detoxification of organophosphorus, carbamate and pyrethroid insecticides through hydrolysis. Toxicology Letters 128, 215-228.

Solé, M., Morcillo, Y., Porte, C., 1998. Imposex in the commercial snail Bolinus brandaris in the northwestern Mediterranean. Environ. Pollut. 99, 241-246.

Solé, M., Baena, M., Arnau, S., Carrasson, M., Maynou, F., Cartes, J., 2009. Muscular biomarker responses in several marine fish species from the NW Mediterranean and their relationship with ecological markers. Comp. Biochem. Physiol. A 154, S27-S27.

Solé, M., Sanchez-Hernandez, J.C., 2015. An in vitro screening with emerging contaminants reveals inhibition of carboxylesterase activity in aquatic organisms. Aquat. Toxicol. 169, 215-222.

Solé, M., Sanchez-Hernandez, J.C., 2018. Elucidating the importance of mussel carboxylesterase activity as exposure biomarker of environmental contaminants of current concern: An in vitro study. Ecol. Indic. 85, 432-439.

Sole, M., Rivera-Ingraham, G., Freitas, R., 2018. The use of carboxylesterases as biomarkers of pesticide exposure in bivalves: A methodological approach. Comparative biochemistry and physiology. Toxicology \& pharmacology : CBP $212,18-24$. 
Solé, M., Freitas, R., Vinas, L., Rivera-Ingraham, G.A., 2020. Biomarker considerations in monitoring petrogenic pollution using the mussel Mytilus galloprovincialis. Environ. Sci. Pollut. Res, in press.

Takahashi, S., Katoh, M., Saitoh, T., Nakajima, M., Yokoi, T., 2009. Different Inhibitory Effects in Rat and Human Carboxylesterases. Drug Metabolism and Disposition 37, 956-961.

Tornero, V., Hanke, G., 2016. Chemical contaminants entering the marine environment from sea-based sources: A review with a focus on European seas. Mar. Pollut. Bull. 112, 17-38.

van der Veen, I., de Boer, J., 2012. Phosphorus flame retardants: Properties, production, environmental occurrence, toxicity and analysis. Chemosphere 88, 1119-1153.

Varo, I., Perini, A., Torreblanca, A., Garcia, Y., Bergami, E., Vannuccini, M.L., Corsi, I., 2019. Time-dependent effects of polystyrene nanoparticles in brine shrimp Artemia franciscana at physiological, biochemical and molecular levels. Sci. Total Environ. 675, 570-580.

Wheelock, C.E., Phillips, B.M., Anderson, B.S., Miller, J.L., Miller, M.J., Hammock, B.D., 2008. Applications of carboxylesterase activity in environmental monitoring and toxicity identification evaluations (TIEs). Rev. Environ. Contam. Toxicol. $195,117-178$.

Xu, Y., Zhang, C., Li, X., Wu, T., Ren, X., Liu, D., 2013. Evaluation of the Inhibitory Effects of Antihypertensive Drugs on Human Carboxylesterase In Vitro. Drug Metabolism and Pharmacokinetics 28, 468-474.

Zhu, G.-F., 2017. Exposure of Bisphenol A (BPA) Derivatives Affect the Metabolic Elimination of Alzheimer's Diseases Treatment Drugs. Latin American Journal of Pharmacy 36, 1753-1759. 
Figure 1. Solubility and lipophilia characteristics of the twelve drugs tested in vitro. Full names as listed in Table 2. A negative relationship was seen between both parameters and a common drug concentration was adopted following mammalian in vitro studies. Log Kow and solubility from ChemSpider database

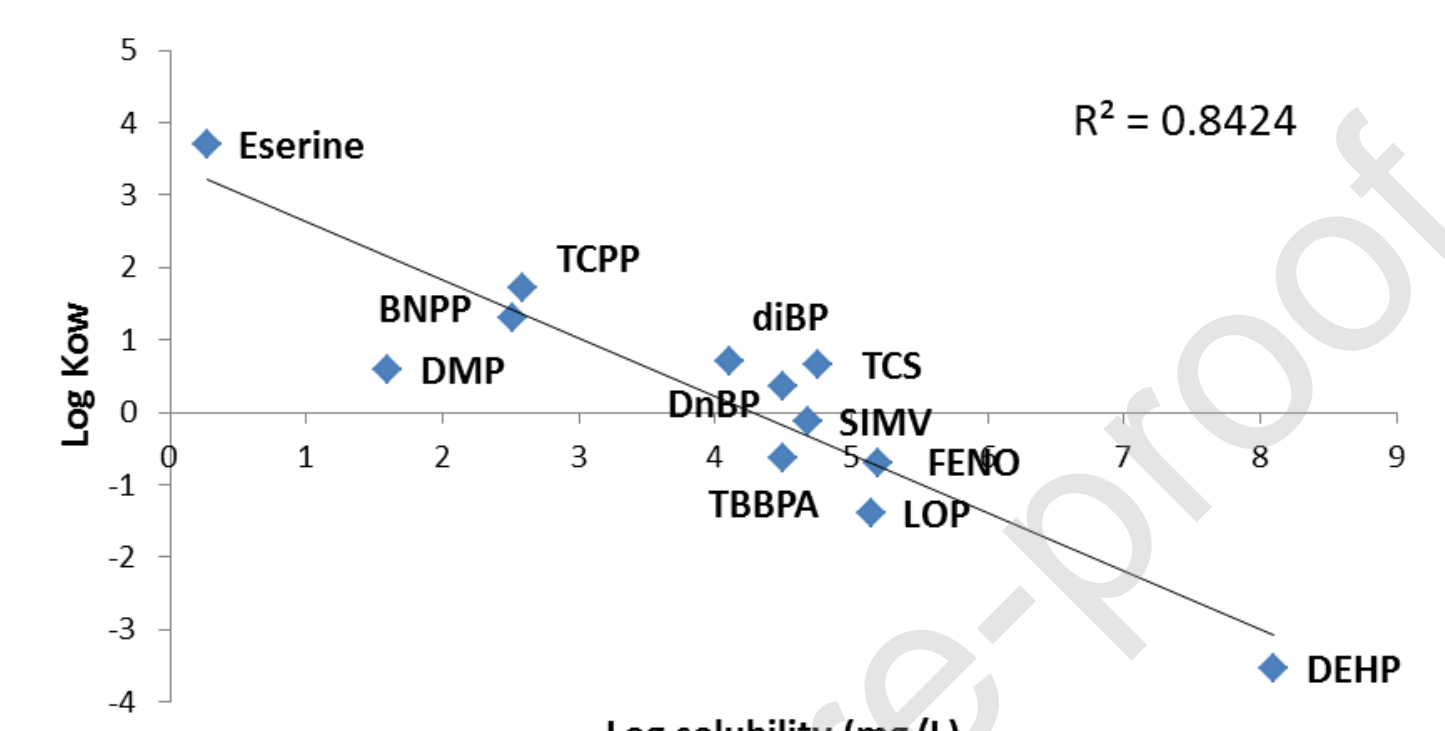

Log solubility $(\mathrm{mg} / \mathrm{L})$

Figure 2. Percentage (\%) of residual CE activity ( $n=6$ independent measures) of recombinant human carboxylesterases (hCE1 and hCE2) after in vitro inhibition with several chemicals of environmental concern at concentration of $10^{-4} \mathrm{M}$ (full names in Table 2) in respect to controls (black line at 100\%). All inhibitions $>20 \%$ were considered significant $(\mathrm{p}<0.05)$.

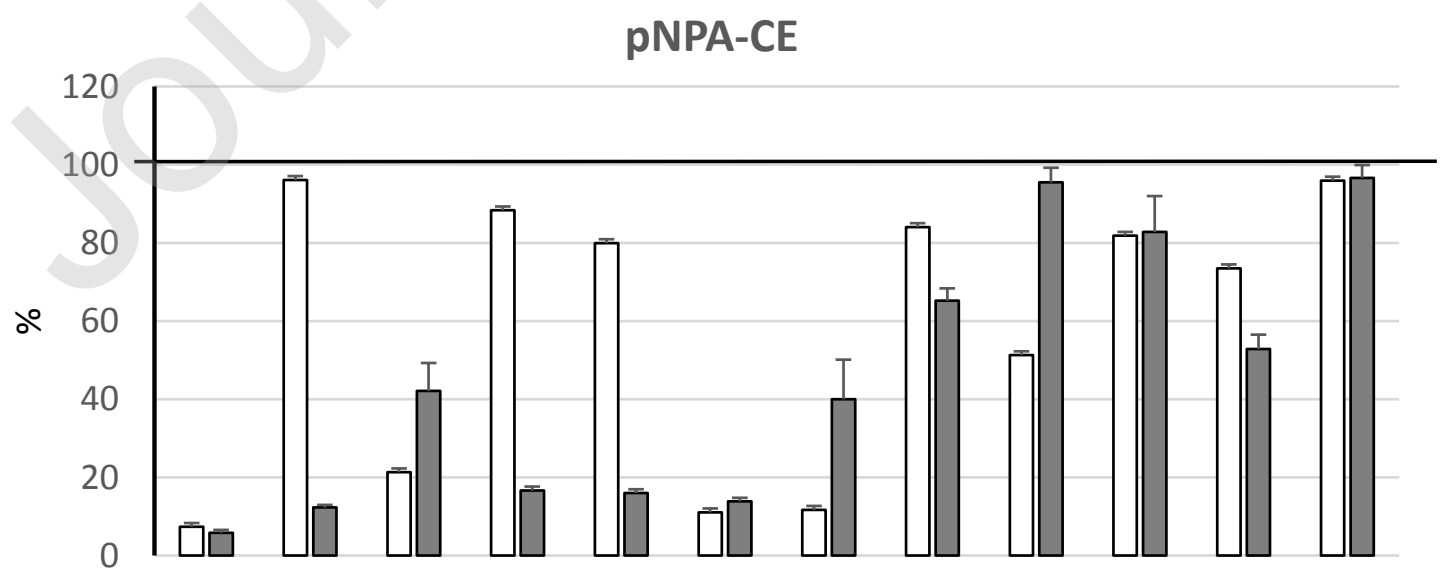




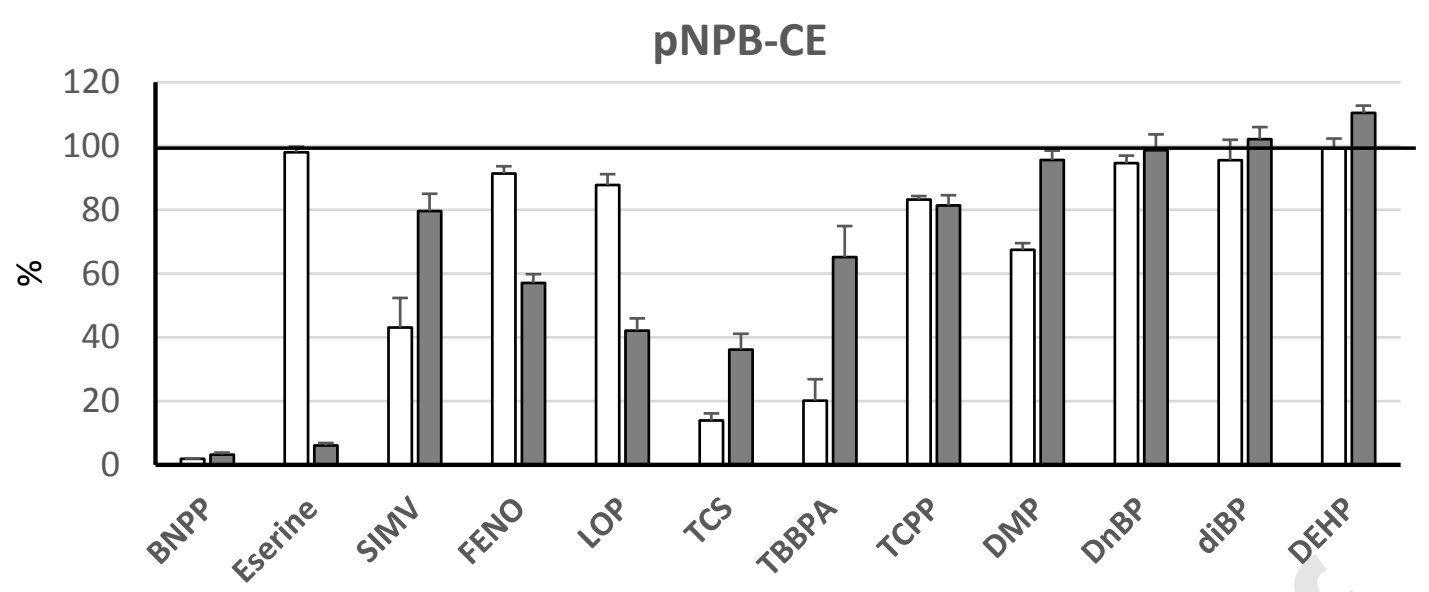

$\square \mathrm{hCE} 1 \square \mathrm{hCE} 2$

Figure 3. Percentage (\%) of residual CE activity ( $n=6$ independent measures) of invertebrate $\mathrm{S} 9$ carboxylesterases using 4 commercial substrates after in vitro inhibition with the organophosphorus pesticide BNPP (concentration $=10^{-4} \mathrm{M}$ ) in respect to control (black line at $100 \%)$. All inhibitions $>20 \%$ were significant $(\mathrm{p}<0.05)$.

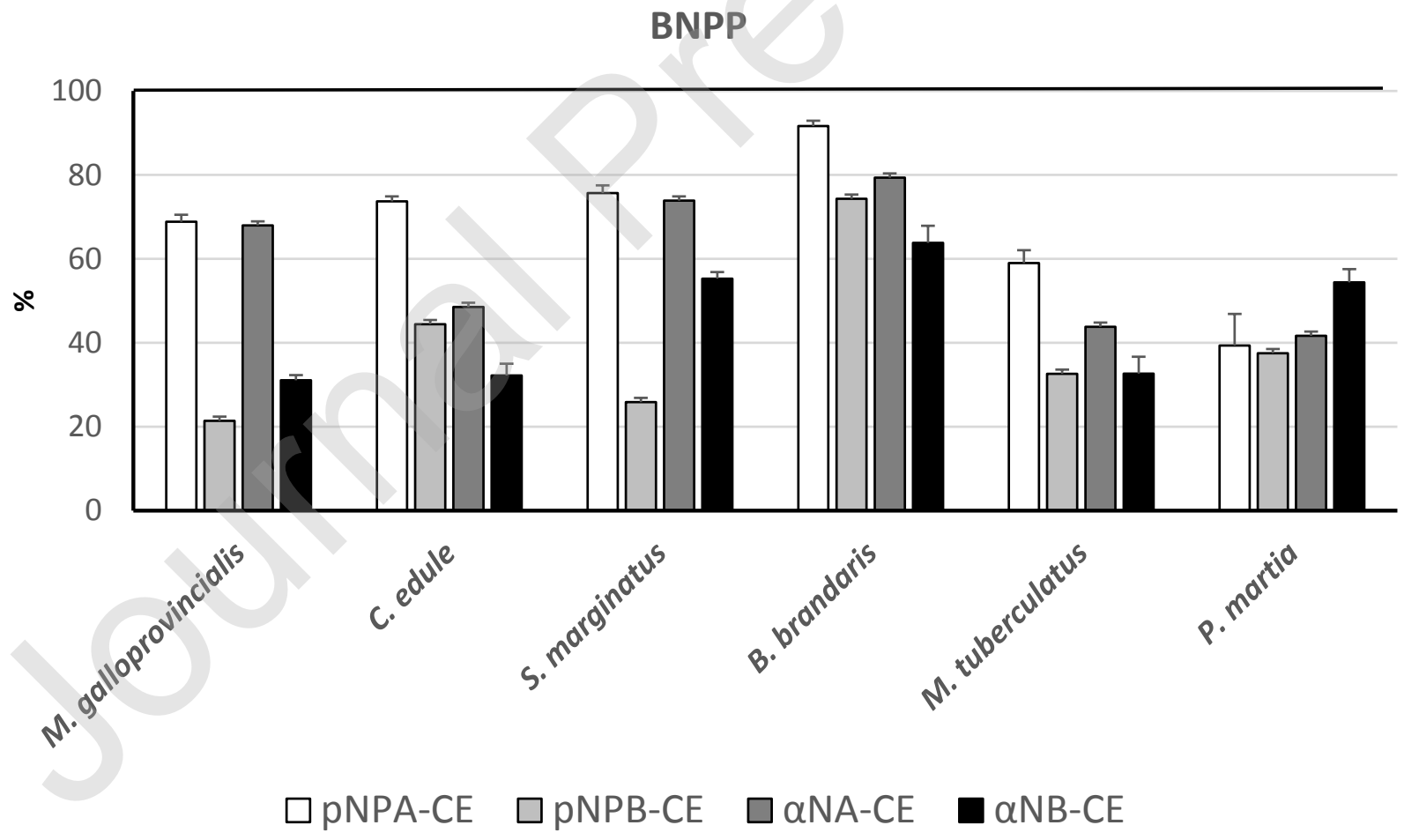

Figure 4. Percentage $(\%)$ of residual invertebrate pNPB-CE activity ( $\mathrm{n}=6$ independent measures) after S9 in vitro inhibition with the model eserine and chemicals of 
environmental concern: TCS, TBBPA and TCPP (in all cases, concentration $=10^{-4} \mathrm{M}$ ) in respect to their respective controls $(100 \%)$. Full names as in Table 2 . * indicate statistically significant differences $(\mathrm{p}<0.05)$.

PNPB-CE

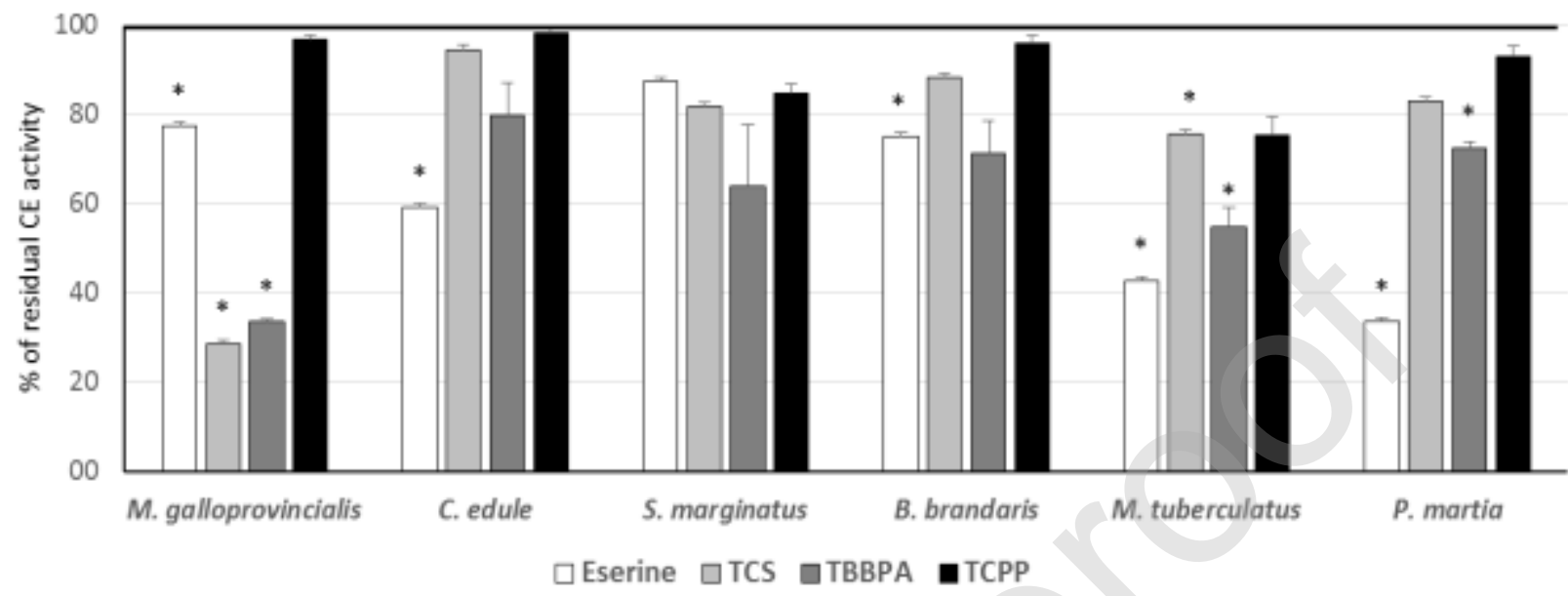


Table 1.Invertebrate species selected to perform baseline activity measures of carboxylesterases (CE) using 4 different substrates. Data are expressed as mean \pm SD for size and mean \pm SEM for activities in $n m o l / m i n / m g$ protein $(n=10)$ for each species and measure. Statistical significant differences $(\mathrm{p}<0.05)$ are indicated as lower case letters for comparisons per each substrate among species and capital letters are comparisons among substrates for a given species. Biometric measures as indicated in ${ }^{1}$ Dallarés et al 2018; ${ }^{2}$ Martín et al., 1995; ${ }^{3}$ Carbonell and Abelló 1998; ${ }^{4}$ Abelló 1990.

\begin{tabular}{|c|c|c|c|c|c|c|}
\hline Species name & $\begin{array}{l}\text { Common } \\
\text { name }\end{array}$ & $\begin{array}{l}\text { Size } \\
(\mathrm{mm})\end{array}$ & $\begin{array}{l}\text { pNPA- } \\
\text { CE }\end{array}$ & pNPB-CE & $\alpha \mathrm{NA}-\mathrm{CE}$ & $\alpha \mathrm{NB}-\mathrm{CE}$ \\
\hline Bivalves & & & & & & \\
\hline $\begin{array}{l}\text { Mytilus } \\
\text { galloprovincialis }\end{array}$ & Mussel & $\begin{array}{l}55.2 \\
\pm 2.7^{1}\end{array}$ & $\begin{array}{l}45.02 \pm \\
2.80 \mathrm{a} \mid \mathrm{A}\end{array}$ & $\begin{array}{l}67.21 \pm \\
5.21 \mathrm{a} \mid \mathrm{B}\end{array}$ & $\begin{array}{c}73.08 \pm \\
5.10 \mathrm{a}, \mathrm{b} \mid \mathrm{B}\end{array}$ & $\begin{array}{l}85.87 \pm \\
5.19 \mathrm{a} \mid \mathrm{C}\end{array}$ \\
\hline $\begin{array}{l}\text { Cerastoderma } \\
\text { edule }\end{array}$ & Cockle & $\begin{array}{l}28.1 \\
\pm 1.8^{1}\end{array}$ & $\begin{array}{l}42.69 \pm \\
3.18 \mathrm{a} \mid \mathrm{A}\end{array}$ & $\begin{array}{l}50.24 \pm \\
4.46 \mathrm{~b} \mid \mathrm{B}\end{array}$ & $\begin{array}{l}65.09 \pm \\
2.71 \mathrm{a} \mid \mathrm{C}\end{array}$ & $\begin{array}{c}121.33 \pm \\
13.10 \mathrm{a}, \mathrm{b} \mid \mathrm{D}\end{array}$ \\
\hline Solen marginatus & $\begin{array}{l}\text { Razor } \\
\text { shell }\end{array}$ & $\begin{array}{l}99.7 \\
\pm 5.6^{1}\end{array}$ & $\begin{array}{l}77.46 \pm \\
4.13 \mathrm{~b} \mid \mathrm{A}\end{array}$ & $\begin{array}{l}83.72 \pm \\
9.05 \mathrm{a} \mid \mathrm{A}\end{array}$ & $\begin{array}{c}191.94 \pm \\
8.03 \mathrm{clB}\end{array}$ & $\begin{array}{c}115.63 \pm \\
9.84 \mathrm{~b} \mid \mathrm{C}\end{array}$ \\
\hline $\begin{array}{l}\text { Gastropod } \\
\text { Bolinus } \\
\text { brandaris }\end{array}$ & $\begin{array}{l}\text { Purple } \\
\text { dye } \\
\text { murex }\end{array}$ & $\begin{array}{l}68.0 \\
\pm 0.9^{2}\end{array}$ & $\begin{array}{l}67.66 \pm \\
4.82 \mathrm{~b} \mid \mathrm{A}\end{array}$ & $\begin{array}{l}69.73 \pm \\
9.72 \mathrm{a} \mid \mathrm{A}\end{array}$ & $\begin{array}{l}48.02 \pm \\
2.63 \mathrm{~d} \mid \mathrm{B}\end{array}$ & $\begin{array}{l}61.45 \pm \\
5.12 \mathrm{c} \mid \mathrm{A}\end{array}$ \\
\hline $\begin{array}{l}\text { Crustacea } \\
\text { Macropipus } \\
\text { tuberculatus } \\
\text { Plesonika martia }\end{array}$ & $\begin{array}{l}\text { Knobby } \\
\text { swim crab } \\
\text { Golden } \\
\text { shrimp }\end{array}$ & $\begin{array}{l}26.0 \\
\pm 1.9^{3} \\
20.8 \\
\pm 1.9^{4} \\
\end{array}$ & $\begin{array}{l}67.88 \pm \\
3.76 \mathrm{~b} \mid \mathrm{A} \\
244.93 \pm \\
24.26 \mathrm{c} \mid \mathrm{A}\end{array}$ & $\begin{array}{c}169.10 \pm \\
8.60 \mathrm{clB} \\
261.36 \pm \\
24.86 \mathrm{~d} \mid \mathrm{A} \\
\end{array}$ & $\begin{array}{c}78.12 \pm \\
4.21 \mathrm{~b} \mid \mathrm{C} \\
366.65 \pm \\
31.37 \mathrm{e} \mid \mathrm{B} \\
\end{array}$ & $\begin{array}{r}114.5 \pm \\
6.01 \mathrm{~b} \mid \mathrm{D} \\
247.96 \pm \\
19.73 \mathrm{c} \mid \mathrm{A} \\
\end{array}$ \\
\hline
\end{tabular}


Table 2. List of the chemicals tested in vitro. Selection was based on Zou et al., (2018) for pesticides and pharmaceuticals and for plastic additives from Hermabessiere et al 2017 and Ozaki et al 2017. FR = flame retardants..n.a data not available.

\begin{tabular}{|c|c|c|c|c|c|}
\hline Compound & Full name & $\begin{array}{l}\text { CAS } \\
\text { numb } \\
\text { er }\end{array}$ & Use & $\begin{array}{l}\text { Action } \\
\text { over } \\
\text { mammali } \\
\text { an CEs }\end{array}$ & $\begin{array}{l}\text { Referenc } \\
\mathrm{e}\end{array}$ \\
\hline \multicolumn{6}{|l|}{ Pesticides } \\
\hline BNPP & $\begin{array}{l}\text { Bis(4-nitrophenyl) } \\
\text { phosphate }\end{array}$ & $\begin{array}{l}645- \\
15-8\end{array}$ & $\begin{array}{l}\text { Organophosphat } \\
\text { e }\end{array}$ & $\begin{array}{l}\text { Inhibits } \\
\text { all CEs }\end{array}$ & $\begin{array}{l}\text { Hatfield } \\
\text { and } \\
\text { Potter, } \\
2011\end{array}$ \\
\hline Eserine & Physostigmine & $\begin{array}{l}57-47- \\
6\end{array}$ & Carbamate & CE2 & $\begin{array}{l}\text { Takahas } \\
\text { hi et al } \\
2009\end{array}$ \\
\hline \multicolumn{6}{|c|}{$\begin{array}{l}\text { Pharmaceutic } \\
\text { als }\end{array}$} \\
\hline SIMV & Simvastatin & $\begin{array}{l}79902 \\
-63-9\end{array}$ & Lipid regulator & $\begin{array}{l}\text { CE1 } \\
\& \text { CE2 }\end{array}$ & $\begin{array}{l}\text { Shimizu } \\
\text { et al., } \\
2014\end{array}$ \\
\hline FENO & Fenofibrate & $\begin{array}{l}49562 \\
-28-9\end{array}$ & Lipid regulator & $\begin{array}{l}\text { CE1 < } \\
\text { CE2 }\end{array}$ & $\begin{array}{l}\text { Fukami } \\
\text { et al., } \\
2010\end{array}$ \\
\hline LOP & Loperamide & $\begin{array}{l}34552 \\
-83-5\end{array}$ & $\begin{array}{l}\text { Antidiarrheal } \\
\text { drug }\end{array}$ & CE2 & $\begin{array}{l}\text { Quinney } \\
\text { et al., } \\
2005\end{array}$ \\
\hline \multicolumn{6}{|l|}{$\begin{array}{l}\text { Plastic } \\
\text { additivess }\end{array}$} \\
\hline TCS & Triclosan & $\begin{array}{l}3380 \\
-34-\end{array}$ & $\begin{array}{l}\text { Antimicrobial } \\
\text { agent }\end{array}$ & $\begin{array}{l}\text { CE1 \& } \\
\text { CE2 }\end{array}$ & $\begin{array}{l}\text { Morisse } \\
\text { au et al., } \\
2009\end{array}$ \\
\hline TBBPA & $\begin{array}{l}\text { Tetrabromobisphe } \\
\text { nol A }\end{array}$ & $\begin{array}{l}79-94- \\
7\end{array}$ & $\begin{array}{l}\text { Organohalogena } \\
\text { ted FR }\end{array}$ & $\begin{array}{l}\text { Inhibits } \\
\text { CE2 }\end{array}$ & $\begin{array}{l}\text { Zhu } \\
2017\end{array}$ \\
\hline TCPP & $\begin{array}{l}\text { Tris(1- } \\
\text { chloropropan-2- } \\
\text { yl) phosphate }\end{array}$ & $\begin{array}{l}13674 \\
-84-5\end{array}$ & $\begin{array}{l}\text { Organophosphor } \\
\text { us FR }\end{array}$ & $\begin{array}{l}\text { Inhibits } \\
\text { several } \\
\text { CEs }\end{array}$ & $\begin{array}{l}\text { Morris } \\
\text { et al., } \\
2014\end{array}$ \\
\hline DMP & dimethyl phthalate & $\begin{array}{l}131- \\
11-3\end{array}$ & Phthalate & $\begin{array}{l}\text { Metabolis } \\
\text { e } \\
\text { phthalates }\end{array}$ & $\begin{array}{l}\text { Ozaki et } \\
\text { al., } 2017\end{array}$ \\
\hline DnBP & Dibutyl phthalate & $\begin{array}{l}84-74- \\
2\end{array}$ & Phthalate & & \\
\hline $\operatorname{diBP}$ & $\begin{array}{l}\text { diisobutyl } \\
\text { phthalate }\end{array}$ & $\begin{array}{l}84-69- \\
5\end{array}$ & Phthalate & & \\
\hline DEHP & Dioctyl phthalate & $\begin{array}{l}117- \\
81-7\end{array}$ & Phthalate & & \\
\hline
\end{tabular}


